\title{
TINJAUAN YURIDIS TERHADAP PELAKSANAAN TUGAS DAN FUNGSI POLISI PAMONG PRAJA DALAM PEMBINAAN KEAMANAN DAN PENEGAKAN HUKUM
}

\author{
Suhaibah $^{(1)}$, Armiwal $^{(2)}$ \\ ${ }^{1}$ Program Studi Ilmu Hukum Fakultas Hukum Universitas Jabal Ghafur \\ ${ }^{2}$ Program Studi Ilmu Sosial Politik Fakultas Sosial Politik Universitas Iskandarmuda Banda Aceh,
}

\begin{abstract}
ABSTRAK
Berdasarkan ketentuan Undang-undang Pemerintahan Daerah, Kepala Daerah mempunyai kewajiban menegakkan peraturan perundang- undangan dan memelihara ketenteraman dan ketertiban masyarakat. Dalam rangka menyelenggarakan ketenteraman dan ketertiban umum serta untuk menegakkan Peraturan Daerah dibentuk Satuan Polisi Pamong Praja sebagai Perangkat Pemerintah Daerah.

Sebagaimana dengan jelas dinyatakan dalam Pasal 14 ayat (1) huruf g Undang-undang No. 2 Tahun 2002 tentang Kepolisian Negara Republik Indonesia yang menyatakan Polri bertugas melakukan koordinasi, pengawasan, dan pembinaan teknis terhadap kepolisian khusus, penyidik pegawai negeri sipil, dan bentuk-bentuk pengamanan swakarsa. Dari ketentuan tersebut terlihat bahwa pihak kepolisian dalam melaksanakan tugas menjaga dan memelihara Kamtibmas dapat melakukan kerja sama dengan penyidik pegawai negeri sipil, dan bentuk-bentuk pengamanan swakarsa seperti halnya SatPol PP.

Kinerja Satuan Polisi Pamong Praja (Sat Pol PP) tidak pemah luput dari perhatian publik, mengingat segala aktivitasnya dengan mudah diketahui melalui pemberitaan di mass media, baik cetak maupun elektronik. Hal ini terlihat dari tindakan aparat Satpol PP dalam penegakan hukum sering berlebihan sehingga terbentuk opini dalam masyarakat bahwa pelaksanaan tugas dan fungsi Satpol PP tidak sesuai yang belaku. Kenyataan ini tentunya tidak sesuai dengan gambaran aparatur pemerintah daerah yang dalam melaksanakan tugasnya menjunjung tinggi norma hukum, norma agama, Hak Asasi Manusia dan norma-norma sosial lainnya yang hidup dan berkembang di masyarakat.
\end{abstract}

Keywords: Pelaksanaan Tugas dan Fungsi.

\section{PENDAHULUAN}

Satuan Polisi Pamong Praja selanjutnya disebut "Sat. Pol.PP" pada awal pembentukannya rnerupakan salah satu unsur penegak hukurn di daerah yang memberikan kontribusi yang sangat berharga bagi konsolidasi dan stabilitas teritorial pada daerahdaerah yang baru diamankan angkatan perang. Saat itu, tugas-tugas yang berada di luar bidang kepolisian negara merupakan masalah spesifik yang ditangani oleh Polisi Pamong Praja, salah satunya menangani 
bidang pemerintahan umum, khususnya dalam pembinaan ketenteraman dan ketertiban didaerah. Oleh karena itu, tidaklah bijaksana apabila peran dan fungsi Sat. Pol PP dalam menyelenggarakan keamanan dan ketertiban masyarakat dipandang berlebihan bahkan dikatakan hendak mengambil alih peran Polri.

Sebaliknya, antara Polri dengan Sat Pol PP harus terjalin sinergitas dalam upaya menjaga dan memelihara Kamtibmas, sebagaimana dengan jelas dinyatakan dalam Pasal 14 ayat (1) huruf g Undang-undang No. 2 Tahun 2002 tentang Kepolisian Negara Republik Indonesia yang menyatakan Polri bertugas melakukan koordinasi, pengawasan, dan pembinaan teknis terhadap kepolisian khusus, penyidik pegawai negeri sipil, dan bentuk-bentuk pengamanan swakarsa. Dari ketentuan tersebut terlihat bahwa pihak kepolisian dalam melaksanakan tugas menjaga dan memelihara Kamtibmas dapat melakukan kerja sama dengan penyidik pegawai negeri sipil, dan bentuk-bentuk pengamanan swakarsa seperti halnya SatPol PP.

Dalam pelaksanaan tugasnya Sat Pol PP diberi wewenang untuk memelihara keamanan dan ketertiban masyarakat. Hal ini didukung oleh dasar pijakan yuridis yang jelas, sebagaimana dinyatakan dalam Undang- Undang Nomor 32 Tahun 2004 tentang Pemerintahan Daerah, khususnya Pasal 13 dan Pasal 14 pada huruf c, yang menyebutkan: urusan wajib yang menjadi kewenangan Pemerintah Daerah meliputi penyelenggaraan ketertiban umum dan ketentraman masyarakat.

Demikian pula dalam Pasal 148 dan Pasal 149 Undang-Undang Nomor 32 Tahun 2004 tentang Pemerintahan Daerah yang mengamanatkan dibentuknya Satuan Polisi Pamong Praja untuk rnembantu Kepala Daerah dalam menegakkan Peraturan Daerah dan penyelenggaraan ketertiban umum serta katentraman masyarakat.

Selanjutnya dalam pelaksanaan tugasnya Satuan Polisi Pamong Praja diatur dalam sebuah peraturan pemerintah, yaitu Peraturan Pemerintah Republik Indonesia Nomor 32 Tahun 2004 Tentang Pedoman Satuan Polisi Pamong Praja.

Di dalam Pasal 1 angka (4) dan angka (5) PP No. 32 Tahun 2004 tersebut di tentukan bahwa :

1. Satuan Polisi Pamong Praja adalah perangkat pemerintah daerah dalam memelihara dan menyelenggarakan ketenteraman dan ketertiban umum serta menegakkan Peraturan Daerah;

2. Polisi Pamong Praja adalah aparatur Pemerintah Daerah yang melaksanakan tugas Kepala Daerah dalam memelihara dan menyelenggarakan ketenteraman dan ketertiban umum, menegakkan Peraturan Daerah dan Keputusan Kepala Daerah.

Selanjutnya dalam Pasal 3 dan 4 ketentuan tersebut juga disebutkan bahwa Pasal 3 yaitu Satuan Polisi Pamong Praja mempunyai tugas memelihara dan menyelenggarakan ketenteraman dan ketertiban umum, menegakkan Peraturan Daerah dan Keputusan Kepala Daerah.

Pasal 4 yaitu dalam melaksanakan tugas sebagaimana dimaksud dalam Pasal 3, Satuan Polisi Pamong Praja menyelenggarakan fungsi :
a. Penyusunan program dan pelaksanaan ketenteraman dan ketertiban umum, penegakan Peraturan Daerah dan Keputusan Kepala Daerah;

b. Pelaksanaan kebijakan pemeliharaan dan penyelenggaraan ketenteraman dan ketertiban umum di Daerah; 
c. Pelaksanaan kebijakan penegakan Peraturan Daerah dan Keputusan Kepala Daerah;

d. Pelaksanaan

koordinasi pemeliharaan dan penyelenggaraan ketenteraman dan ketertiban umum serta penegakan Peraturan Daerah, Keputusan Kepala Daerah dengan aparat Kepolisian Negara, Penyidik Pegawai Negeri Sipil (PPNS) dan atau aparatur lainnya;

e. Pengawasan terhadap masyarakat agar mematuhi dan menaati Peraturan Daerah dan Keputusan Kepala Daerah.

Dalam Pasal 7 PP No. 32 Tahun 2004, juga ditentukan bahwa: Dalam melaksanakan tugasnya, Polisi Pamong Praja wajib :

a. Menjunjung tinggi norma hukum, norma agama, hak asasi manusia dan norma-norma sosial lainnya yang hidup dan berkembang dimasyarakat;

b. Membantu menyelesaikan perselisihan warga masyarakat yang dapat mengganggu ketenteraman dan ketertiban umum;

c. Melaporkan kepada Kepolisian Negara atas ditemukannya atau patut diduga adanya tindak pidana;

d. Menyerahkan kepada PPNS atas ditemukannya atau patut diduga adanya pelanggaran terhadap Peraturan Daerah dan Keputusan Kepala Daerah.

Secara khusus mengenai tugas dan fungsi Satpol PP dan Wilayatul Hisbah di tingkat Kota Banda Aceh diatur dalam Peraturan Walikota Nomor 44 Tahun 2009 tentang Tugas Pokok dan Fungsi Satpol PP dan Wilayatul Hisbah Kota Banda Aceh. Pasal 3 dan Pasal 4 Peraturan Walikota Nomor 44 Tahun 2009 menentukan bahwa:

Pasal 3 Yaitu :

1) Satpol PP dan $\mathrm{WH}$ merupakan bagian perangkat daerah di bidang penegakan Perda dan atau Qanun, Ketertiban Umum dan Ketentraman Masyarakat.

2) Satpol PP dan WH dipimpin oleh seorang kepala berkedudukan dibawah dan bertanggung jawab langsung kepada walikota dan Sekda

3) Kepala Satpol PP mempunyai tugas memelihara, menyelenggarakan ketentraman dan ketertiban umum, menegakkan Peraturan Daerah dan atau Qanun Peraturan Walikota, Keputusan Walikota, dan pelaksanaan syariat Islam serta melakukan sosialisasi, pengawasan, pembinaan, penyidikan dan pelaksanaan peratuan perundang-undangan dan advokasi syariat Islam.

Pasal 4 Yaitu Dalam melaksanakan tugas sebagaimana dimaksud dalam Pasal 3 ayat (3) Kepala Satpol PP dan WH menyelenggarakan fungsi:

a. Pelaksanaan tatausaha kesatuan

b. Pelaksanaan penyusunan rencana kerja kantor

c. Penatusahaan keuangan dan asset

d. Pembinaan kepegawaian

e. Perumusan, pengoordinasian dan pelaksanaan kebijakan bidang ketentraman dan ketertiban umum serta penegakan peraturan perundangan-undangan dan syariat Islam

f. Penyisinan operasisonal

petunjuk penegakan peraturan perundanganundangan dan syariat Islam

g. Pelaksanaan kebijakan pemeliharaan dan penyelenggaraan ketentraman dan ketertiban umum daerah

h. Penyusunan program kegiatan pembinaan ketentraman dan ketertuban masyarakat

i. Pelaksanaan peraturan perundanganundangan dan syariat Islam 
$\begin{array}{llr}\text { j. } & \text { Pembinaan dalam rangka } \\ \text { pengembangan } & \text { kapasitas } & \text { yang }\end{array}$ meliputi pembinaan personil ketatalaksanaan, sarana dan prasarana kerja satuan polisi pamong praja dan wilayatul hisbah

k. Pelaksanaan koordinasi pembinaan, pemeliharaan, dan penyelenggaraan ketentraman dan ketertiban umum serta penegakan peraturan perundangan-undangan dan syariat Islam dengan aparat epolisian negara, Penyidik Pegawai Negeri Spil (PPNS) dan aparatur lainnya

1. Pengawasan terhadap masyarakat agar mematuhi peraturan perundangan-undangan dan syariat Islam

m. Pembinaan dan pengelolaan administrasi umum yang. meliputi pelaksanaan kepegawaian, perlengkapan, organisasi dan ketatalaksanaan

n. Pengevaluasian pelaksanaan tugas dan laporan o. Pembinaan kelompok jabatan fungsional, dan

o. Pelaksanaan tugas-tugas kedinasan lainnya yang diberikan oleh walikota sesuai dengan tugas dan fungsinya.

Hasil penelitiaan di Kota Banda Aceh diketahui bahwa Satpol PP selain berpedoman pada ketentuan PP No. 32 Tahun 2004 dan juga berpedoman pada ketentuan tersebut. Selain itu, dalam ketentuan Undang- undang No. 11 Tahun 2006 tentang Pemerintahan Aceh juga diatur bahwa Satpol PP yang di dalamnya mencakup wilayatul hisbah juga berperan sebagai penegak syari'at Islam yang bekerja sama dengan pihak kepolisian dalam penyidikan.

$$
\text { Kinerja Satuan Polisi }
$$

Pamong Praja (Sat Pol PP) tidak pemah luput dari perhatian publik, mengingat segala aktivitasnya dengan mudah diketahui melalui pemberitaan di mass media, baik cetak maupun elektronik. Hal ini terlihat dari tindakan aparat Satpol PP dalam penegakan hukum sering berlebihan sehingga terbentuk opini dalam masyarakat bahwa pelaksanaan tugas dan fungsi Satpol PP tidak sesuai yang belaku. Kenyataan ini tentunya tidak sesuai dengan gambaran aparatur pemerintah daerah yang dalam melaksanakan tugasnya menjunjung tinggi nonna hukum, norma agama, Hak Asasi Manusia dan normanorma sosial lainnya yang hidup dan berkembang di masyarakat.

Kondisi ini menunjukkan bahwa dalam pelaksanaan di lapangan kewenangan, fungsi dan tugasnya merugikan masyarakat karena terlalu represif, dan terkesan arogan sehingga melanggar ketentuan mengenai kewenangan, fungsi dan tugasnya yang diatur Pasal 3, 4 dan Pasal 7 sebagaimana yang telah diuraikan di atas.

Berdasarkan uraian di atas penulis tertarik untuk menelaah lebih lanjut mengenai:

1) Apakah tugas dan fungsi Satuan polisi Pamong Praja di Kota Banda Aceh. ?

2) Apakah hambatan yang ditemui dalam pelaksanaan tugas dan fungsi Satpol PP di Kota Banda Aceh ?

3) Apakah upaya pemerintah daerah Kota Banda Aceh dalam mewujudkan tugas dan fungsi Satpol PP ?

LANDASAN TEORITIS TENTANG TUGAS DAN FUNGSI SATUAN POLISI PAMONG PRAJA.

\section{A. Pengertian Satuan Polisi Pamong Praja (Satpol PP). \\ Di dalam Pasal 1 angka (4)} dan angka (5) PP No. 32 Tahun 2004 tersebut di tentukan bahwa :

1. Satuan Polisi Pamong Praja adalah perangkat pemerintah daerah dalam 
memelihara dan menyelenggarakan ketenteraman dan ketertiban umum serta menegakkan Peraturan Daerah;

2. Polisi Pamong Praja adalah aparatur Pemerintah Daerah yang melaksanakan tugas Kepala Daerah dalam memelihara dan menyelenggarakan ketenteraman dan ketertiban umum, menegakkan Peraturan Daerah dan Keputusan Kepala Daerah.

Selanjutnya dalam Pasal 3 dan 4 ketentuan tersebut juga disebutkan bahwa Pasal 3 yaitu Satuan Polisi Pamong Praja mempunyai tugas memelihara dan menyelenggarakan ketenteraman dan ketertiban umum, menegakkan Peraturan Daerah dan Keputusan Kepala Daerah.

Pasal 4 yaitu dalam melaksanakan tugas sebagaimana dimaksud dalam Pasal 3, Satuan Polisi Pamong Praja menyelenggarakan fungsi :

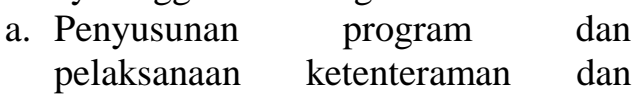
ketertiban umum, penegakan Peraturan Daerah dan Keputusan Kepala Daerah;

b. Pelaksanaan kebijakan pemeliharaan dan penyelenggaraan ketenteraman dan ketertiban umum di Daerah;

c. Pelaksanaan kebijakan penegakan Peraturan Daerah dan Keputusan Kepala Daerah;

d. Pelaksanaan koordinasi pemeliharaan dan penyelenggaraan ketenteraman dan ketertiban umum serta penegakan Peraturan Daerah, Keputusan Kepala Daerah dengan aparat Kepolisian Negara, Penyidik Pegawai Negeri Sipil (PPNS) dan atau aparatur lainnya;

e. Pengawasan terhadap masyarakat agar mematuhi dan menaati Peraturan Daerah dan Keputusan Kepala Daerah.
Dalam Pasal 7 PP No. 32 Tahun 2004, juga ditentukan bahwa: Dalam melaksanakan tugasnya, Polisi Pamong Praja wajib :

a. Menjunjung tinggi norma hukum, norma agama, hak asasi manusia dan norma-norma sosial lainnya yang hidup dan berkembang dimasyarakat;

b. Membantu menyelesaikan perselisihan warga masyarakat yang dapat mengganggu ketenteraman dan ketertiban umum;

c. Melaporkan kepada Kepolisian Negara atas ditemukannya atau patut diduga adanya tindak pidana;

d. Menyerahkan kepada PPNS atas ditemukannya atau patut diduga adanya pelanggaran terhadap Peraturan Daerah dan Keputusan Kepala Daerah.

B. Unsur Pelaksana Penegakan Hukum Dan Peraturan Daerah

Dalam rangka mengantisipasi perkembangan dan dinamika kegiatan masyarakat seirama dengan tuntutan era globalisasi dan otonomi daerah, maka kondisi ketenteraman dan ketertiban umum daerah yang kondusif merupakan suatu kebutuhan mendasar bagi seluruh masyarakat untuk meningkatkan mutu kehidupannya.

Berdasarkan ketentuan Undangundang Pemerintahan Daerah, Kepala Daerah mempunyai kewajiban menegakkan peraturan perundangundangan dan memelihara ketenteraman dan ketertiban masyarakat. Dalam rangka menyelenggarakan ketenteraman dan ketertiban umum serta untuk menegakkan Peraturan Daerah dibentuk Satuan Polisi Pamong Praja sebagai Perangkat Pemerintah Daerah.

Hal ini tertuang dalam penjelasan umum dari Peraturan Pemerintah Nomor 32 Tahun 2004 Tentang Pedoman Satuan Polisi Pamong Praja, bahwa Satuan Polisi Pamong Praja tersebut mempunyai misi strategis dalam membantu Kepala Daerah untuk 
menciptakan suatu kondisi daerah yang tenteram, tertib dan teratur sehingga penyelenggaraan roda pemerintahan dapat berjalan dengan lancer dan masyarakat dapat melakukan kegiatannya dengan aman. Oleh karena itu, disamping menegakkan Peraturan Daerah, Polisi Pamong Praja juga dituntut untuk menegakkan kebijakan Pemerintah Daerah lainnya yaitu Keputusan Kepala Daerah

Untuk mengoptimalkan kinerja Satuan Polisi Pamong Praja, perlu dibangun kelembagaan yang handal, sehingga tujuan terwujudnya kondisi daerah yang tenteram dan tertib dapat direalisasikan. Munculnya gangguan ketenteraman dan ketertiban umum dan timbulnya pelanggaran Peraturan Daerah identik dengan kepadatan jumlah penduduk di suatu Daerah.

Di Provinsi Nanggroe Aceh Darussalam dalam penegakan ketentuan ataupun peraturan daerah juga melibatkan Sat Pol PP. Dalam hal ini kewenangan pada Sat Pol PP untuk memelihara keamanan dan ketertiban masyarakat, didukung oleh dasar pijakan yuridis yang jelas, sebagaimana dinyatakan dalam Undang-Undang Nomor 32 Tahun 2004 tentang Pemerintahan Daerah, khususnya Pasal 13 dan Pasal 14 pada huruf c, yang menyebutkan: urusan wajib yang menjadi kewenangan Pemerintah Daerah meliputi penyelenggaraan ketertiban umum dan ketentraman masyarakat.

Di dalam Pasal 1 angka (4) dan angka (5) PP No. 32 Tahun 2004 tersebut di tentukan bahwa :

1. Satuan Polisi Pamong Praja adalah perangkat pemerintah daerah dalam memelihara dan menyelenggarakan ketenteraman dan ketertiban umum serta menegakkan Peraturan Daerah;

2. Palisi Pamong Praja adalah aparatur Pemerintah Daerah yang melaksanakan tugas Kepala Daerah dalam memelihara dan menyelenggarakan ketenteraman dan ketertiban umum, menegakkan Peraturan Daerah dan Keputusan Kepala Daerah.

Selanjutnya dalam Pasal 3 dan 4 ketentuan tersebut juga disebutkan bahwa:Pasal 3 yaitu Satuan Polisi Pamong Praja mempunyai tugas memelihara dan menyelenggarakan ketenteraman dan ketertiban umurn, menegakkan Peraturan Daerah dan Keputusan Kepala Daerah.

Pasal 4 yaitu Dalam melaksanakan tugas sebagaimana dimaksud dalam Pasal 3, Satuan Polisi Pamong Praja menyelenggarakan fungsi :

a. Penyusunan program dan pelaksanaan ketenteraman dan ketertiban umum, penegakan Peraturan Daerah dan Keputusan Kepala Daerah;

b. Pelaksanaan kebijakan pemeliharaan dan penyelenggaraan ketenteraman dan ketertiban umum di Daerah;

c. Pelaksanaan kebijakan penegakan Peraturan Daerah dan Keputusan Kepala Daerah;

d. Pelaksanaan koordinasi pemeliharaan dan penyelenggaraan ketenteraman dan ketertiban umum serta penegakan Peraturan Daerah, Keputusan Kepala Daerah dengan aparat Kepolisian Negara, Penyidik Pegawai Negeri Sipil (PPNS) dan atau aparatur lainnya;

e. Pengawasan terhadap masyarakat agar mematuhi dan menaati Peraturan Daerah dan Keputusan Kepala Daerah.

Berdasarkan ketentuan tersebut dapat diketahui bahwa tugas Satuan Polisi Pamong Praja di Provinsi Nanggroe Aceh Darussalam yang juga meliputi Kota Banda Aceh diketahui bahwa Satpol PP selain berpedoman pada ketentuan PP No. 32 Tahun 2004 dan juga berpedoman pada ketentuan tersebut. Selain itu, dalam ketentuan Undang-undang No. 11 Tahun 2006 
tentang Pemerintahan Aceh juga diatur bahwa Satpol PP yang di dalamnya mencakup wilayatul hisbah juga berperan sebagai penegak syari'at Islam yang bekerja sama dengan pihak kepolisian dalam penyidikan.

Dengan melihat pada kewenangan yang diberikan kepada Sat Pol PP, tidak dapat dipungkiri bahwa keberadaan Satpol PP sangat penting dan strategis dalam penyelenggaraan pemerintahan daerah sesuai dengan lingkup tugasnya, termasuk di dalamnya penyelenggaraan perlindungan masyarakat (Linmas).

\section{Satuan Polisi Pamong Praja Sebagai Unsur Penegakan Hukum Di Daerah}

Satuan Polisi Pamong Praja, atau disingkat Satpol PP, adalah perangkat Pemerintah Daerah dalam memelihara ketentraman dan ketertiban umum serta menegakkan Peraturan Daerah. Satpol PP merupakan perangkat daerah yang dapat berbentuk Dinas Daerah atau Lembaga Teknis Daerah. ${ }^{1}$

Polisi Pamong Praja didirikan di Yogyakarta pada tanggal 3 Maret 1950 untuk mewadahi sebagian ketugasan pemerintah daerah. Sebenarnya ketugasan ini telah dilaksanakan pemerintah sejak zaman kolonial. ${ }^{2}$

Satpol PP dapat berkedudukan di Daerah Provinsi dan Daerah Kabupaten/Kota. Di Daerah Provinsi, Satuan Polisi Pamong Praja dipimpin oleh Kepala yang berada di bawah dan bertanggung jawab kepada Gubemur melalui Sekretaris Daerah. Di Daerah Kabupaten/Kota, Satuan Polisi Pamong Praja dipimpin oleh Kepala yang berada di bawah dan bertanggung jawab kepada Bupati/Walikota melalui Sekretaris Daerah. $^{3}$
Organisasi dan tata kerja Satuan Polisi Pamong Praja ditetapkan dengan Peraturan Daerah, sehingga antar daerah bisa saja memiliki nama, organisasi, dan tata kerja yang berbeda-beda.

Peraturan Pemerintah Nomor 32

Tahun 2004 tentang Pedoman Satuan Polisi Pamong Praja, maka dapat disimpulkan tugas Satuan Polisi Pamong Praja adalah:

1. Memelihara ketentraman dan ketertiban umum, menegakan Peraturan Daerah, Peraturan Kepala Daerah serta memberikan perlindungaan kepada masyarakat.

2. Mewujudkan sikap kepatuhan masyarakat dalam melaksanakan Peraturan Daerah dan Peraturan Kepala Daerah lainnya dalam menunjang keberhasilan penyelenggaraan Otonomi Daerah.

3. Melakukan pengawasan dan pengamanan Peraturan Daerah dan Peraturan Kepala Daerah serta melakukan penindakan kepada masyarakat dan badan hukum lainnya yang melanggar Peraturan Daerah.

4. Membantu Kepala Daerah dalam memelihara ketentraman dan ketertiban dan berupaya sebagai mediator dalam penanganan berbagai masalah baik perorangan, kelompok agar masyarakat dapat hidup tentram dan sejahtera.

Untuk melaksanakan tugasnya Satuan Polisi Pamong Praja mempunyai fungsi sebagai berikut :

1. Perumusan kebijakan pemeliharaan dan penyelenggaraan ketentraman dan ketertiban umum dan Lirunas di daerah.

2. Perumusan kebijakan penegakan Peraturan Daerah dan Keputusan Kepala Daerah.

3. Pembinaan dan pengawasan terhadap masyarakat agar mematuhi dan mentaati Peraturan Perundangundangan.

4. Menyusun program dan pelaksanaan Linmas ketentraman dan ketertiban 
umum, penegakan Peraturan Daerah dan Keputusan Kepala Daerah.

5. Koordinasi pelaksanaan pemeliharaan dan penyelenggaraan ketentraman dan ketertiban umum serta menegakan Peraturan Daerah.

6. Keputusan Kepala Daerah dan Peraturan Perundang-undangan lainnya dan aparat.

Untuk menjalankan tugas pokok dan fungsi Satuan Polisi Pamong Praja, maka didukung oleh :

1. Kepala Satuan Polisi Pamong Praja

2. Kepala Sub Bagian Tata Usaha

3. Kepala Seksi Perlindungan Masyarakat

4. Kepala Seksi Ketentraman dan Ketertiban Umum

5. Kepala Seksi Penyidikan dan Penegakan Peraturan Daerah .

6. Bantuan Polisi Pamong Praja pada wilayah kecamatan yang tersebar di setiap kecamatan dalam wilayah.

7. Sekretariat Satuan Polisi Pamong Praja

Dalam rangka mengantisipasi perkembangan dan dinamika kegiatan masyarakat seirama dengan tuntutan era globalisasi dan otonomi daerah, maka kondisi ketenteraman dan ketertiban umum daerah yang kondusif merupakan suatu kebutuhan mendasar bagi seluruh masyarakat untuk meningkatkan mutu kehidupannya.

Mengenai wewenang dari Satpol PP Pasal 5 PP No. Tahun 2004 menentukan bahwa :

Polisi Pamong Praja berwenang :

a. Menertibkan dan menindak warga masyarakat atau badan hukum yang mengganggu ketentraman dan ketertiban umum;

b. Melakukan pemeriksaan terhadap warga masyarakat atau badan hukum yang melakukan pelanggaran atas Peraturan Daerah dan Keputusan Kepala Daerah;

c. Melakukan tindakan represif non yustisial terhadap warga d. Masyarakat atau badan hukum yang melakukan pelanggaran atas Peraturan Daerah dan Keputusan Kepala Daerah.

Menertibkan yang dimaksud adalah tindakan dalam rangka upaya menumbuhkan ketaatan warga masyarakat agar tidak melanggar ketenteraman dan ketertiban umum serta Peraturan Daerah dan Keputusan Kepala Daerah. Pemeriksaan adalah pemeriksaan awal sampai dengan dilimpahkannya hasil pemeriksaan kepada penyidik apabila ditemukannya bukti awal adanya pelanggaran. Sedangkan menindak adalah tindakan yang dilakukan oleh Polisi Pamong Praja terhadap anggota masyarakat badan hukum lainnya yang melanggar ketentuan dan atau obyek tertentu yang tidak sesuai dengan Peraturan Daerah, dan Keputusan Kepala Daerah yang bersifat tindakan represif non yustisial

Polisi Pamong Praja mempunyai hak kepegawaian sebagai Pegawai Negeri Sipil dan mendapatkan fasilitas lain sesuai dengan tugas dan fungsinya berdasarkan peraturan perundangundangan (Pasal 6). Sedangkan mengenai tugasnya diatur dalam ketentuan Pasal Pasal 7 PP No. Tahun 2004.

Norma sosial lain yang dimaksud adalah norma-nonna sosial lainnya adalah adat atau kebiasaan yang diakui sebagai aturan/etika yang mengikat secara moral kepada masyarakat setempat. Membantu menyelesaiankan perselisihan adalah upaya pencegahan agar perselisihan antar warga masyarakat tersebut tidak menimbulkan gangguan ketenteraman dan ketertiban umum.

Sedangkan tindak pidana adalah tindak pidana di luar yang diatur dalam Peraturan Daerah. Bagi Polisi Pamong Praja yang merangkap sebagai PPNS, apabila mengetahui adanya pelanggaran terhadap Peraturan Daerah atau 
Keputusan Kepala Daerah oleh warga masyarakat, dapat langsung mengadakan penyidikan.

Dengan demikian tugas
penegakan hukum akan sangat merepotk:an anggota kepolisian yang bertugas di Aceh karena mereka tidak dibekali secara memadai tentang hukum yang berlaku di Aceh; dan lebih dari itu sekiranya diberikan pembekalan akan tetap merepotkan karena mobilitas di kalangan anggota kepolisian relatif tinggi sekali. Boleh jadi sebelurn mereka mahir memahami dan melaksanakan aturan jinayah yang berlaku di Aceh, mereka sudah dipindah tugaskan lagi ke luar Aceh

\section{PELAKSANAAN TUGAS DAN FUNGSI SATUAN POLISI PAMONG PRAJA}

Dalam era otonomi daerah terjadi pelbagai perubahan mendasar dalam kehidupan masyarakat sehingga peran tugas dan fungsi lembaga-lembaga pemerintahan di: daerah dituntut dapat mengantisipasi segala perubahan tersebut. Peran, tugas dan fungsi lembaga-lembaga pemerintahan itu seringkali belum dipahami dalam konteks sistem pemerintahan di daerah, sebagai sebuah kerja tim yang satu sama lain saling memengaruhi. Ada kesan seolah-olah lembaga-Iembaga pemerintahan di daerah berjalan sendirisendiri tanpa pedoman yang jelas, euforia reformasi memperumit situasi tersebut.

Demikian pula halnya dengan Sat Pol PP, di mana dalam pelaksanan tugasnya gerak Jangkah Satuan Polisi Pamong Praja (Sat Pol PP) tidak pernah luput dari perhatian publik, mengingat segala aktivitasnya dengan mudah diketahui melalui pemberitaan di mass media, baik cetak maupun elektronik. Sayangnya, image yang terbentuk di benak masyarakat atas tindakan aparat Sat Pol PP sangat jauh.dari sosok ideal, yang sejatinya menggambarkan aparatur pemerintah daerah yang dalam melaksanakan tugasnya menjunjung tinggi norma hukum, norma agama, Hak Asasi Manusia dan norma-norma sosial lainnya yang hidup dan berkembang di masyarakat.

Munculnya gambaran miring terhadap aparat Polisi Pamong Praja (Pol PP) adalah karena seringnya masyarakat menyaksikan tindakan represif dalam melaksanakan tugas penegakan hukum, sehingga menimbulkan kesan arogan dari aparat daerah tersebut saat menjalankan perannya dalam memelihara dan menyelenggarakan keamanan dan ketertiban umum. Hal ini terlihat dari penggusuran pedagang kaki lima di kawasan Pasar Aceh dan Peunayong, pembongkaran bangunan liar di Kawasan Beurawe dan juga penutupan beberapa usaha salon dan usaha lain yang diduga tidak memiliki izin dan mendapat perlawanan dari pemiliknya.

Pembongkaran bangunan liar, penertiban pedagang kaki lima, dan gelandangan, yang sering berujung bentrokan fisik, merupakan gambaran keseharian yang sering disuguhkan oleh aparat Pol PP, sekalipun tindakantindakan represif tersebut hanyalah sebagian dari fungsi dan peran Pol PP, sebagai pengemban penegakan hukum non yustisial di daerah. Oleh karena itu, tidak berlebihan apabila kemudian masyarakat mencap aparat Pol PP sebagai aparat yang kasar, arogan, penindas masyarakat kecil, serta sebutan-sebutan lain yang tidak enak didengar.Ditambah dengan peran media massa yang sering membumbuinya dengan berita berita sensasional, makin miringlah penggambaran tentang tentang bagaimana sejatinya fungsi dan peran Pol PP dalam rangka pembinaan keamaman dan penegakan hukum. Gambaran ini penting untuk Satpol PP. Terlepas dari benar tidaknya gambaran masyarakat tentang Sat Pol PP, dalam tulisan ini saya mencoba untuk menyegarkan ingatan dikemukakan 
guna diperolehnya kesamaan pandangan, baik dari masyarakat, Sat Pol PP, maupun pemangku kepentingan lainnya tnengenai ', sosok Sat Pol PP yang sesungguhnya.

Sat Pol PP sebagaimana dijelaskan sebelumnya telah memberikan kontribusi yang sangat berharga bagi konsolidasi dan stabilitas teritorial di daerah khusnya yang menangani bidang pemerintahan umum, khususnya dalam pembinaan ketenteraman dan ketertiban di daerah. Dalam hal ini peran dan fungsi Pol PP dalam menyelenggarakan keamanan dan ketertiban masyarakat merupakan peran yang berlebihan seakan-akan hendak mengambil alih peran Polri.

Sebaliknya, antara Polri dengan Sat Pol PP harus terjalin sinergitas dalam upaya menjaga dan memelihara Kamtibmas, sebagaimana dengan jelas dinyatakan dalam Pasal 14 ayat (1) huruf g Undang-undang No. 2 Tahun 2002 tentang Kepolisian Negara Republik Indonesia yang menyatakan Polri bertugas melakukan koordinasi, pengawasan, dan pembinaan teknis terhadap kepolisian khusus, penyidik pegawai negeri sipil, dan bentuk-bentuk pengamanan swakarsa.

Dengan demikian, diberikannya kewenangan pada Sat Pol PP untuk memelihara keamanan dan ketertiban masyarakat bukanlah tanpa alasan. Dengan melihat pada kewenangan yang diberikan kepada Sat Pol PP, tidak dapat dipungkiri bahwa keberadaan Satpol PP sangat penting dan strategis dalam penyelenggaraan pemerintahan daerah sesuai dengan lingkup tugasnya, termasuk di dalamnya penyelenggaraan perlindungan masyarakat (Linmas). Secara umum tugas Sat Pol PP dapat diuraikan antara lain adalah :

1. Memelihara ketentraman dan ketertiban umum, menegakan Peraturan Daerah, Peraturan Kepala Daerah serta memberikan perlindungan kepada masyarakat.
2. Mewujudkan sikap kepatuhan masyarakat dalam melaksanakan Peraturan Daerah dan Peraturan Kepala Daerah lainnya dalam menunjang keberhasilan penyelenggaraan Otonomi Daerah.

3. Melakukan pengawasan dan pengamanan Peraturan Daerah dan Peraturan Kepala Daerah serta melakukan penindakan kepada masyarakat dan badan hukum lainnya yang melanggar Peraturan Daerah.

4. Membantu Kepala Daerah dalam memelihara ketentraman dan ketertiban dan berupaya sebagai mediator dalam penanganan berbagai masalah baik perorangan, kelompok agar masyarakat dapat hidup tentram dan sejahtera

Untuk melaksanakan tugasnya

Satuan Polisi Pamong Praja mempunyai fungsi:

1. Perumusan kebijakan pemeliharaan dan penyelenggaraan ketentraman dan ketertiban umum dan Linmas di daerah.

2. Perumusan kebijakan penegakan Peraturan Daerah dan Keputusan Kepala Daerah.

3. Pembinaan dan pengawasan terhadap masyarakat agar mematuhi dan mentaati Peraturan Perunclangundangan.

4. Menyusun program dan pelaksanaan Linmas ketentraman dan ketertiban umum, penegakan Peraturan Daerah dan Keputusan Kepala Daerah.

5. Koordinasi pelaksanaan pemeliharaan dan penyelenggaraan ketentraman clan ketertiban umwn serta menegakan Peraturan Daerah, Keputusan Kepala Daerah dan Peraturan Perundang-undangan lainnya dan aparat Kepolisian Negara, Penyidik PNS dan atau aturan lainnya.

6. Dengan demikian, dapat dikatakan bahwa Satuan Palisi Parnong Praja memegang peran yang cukup besar dalam penyelenggaraan 
pemerintahan didaerah khususnya dalam penegakan hukum yang menyangkut Peraturan Daerah, Keputusan Kepala Daerah dan Peraturan Perundang-undangan lainnya dan aparat Kepolisian Negara, Penyidik PNS dan atau aturan lainnya.

Dalam praktiknya di Provinsi Nanggroe Aceh Darussalam termasuk di Kota Banda Aceh Satpol PP saat ini digabung dengan Wilayatul Hisbah. Satpol PP dan wilayatul hisbah ini yang merupakan aparatur pemerintah daerah yang melaksanakan tugas membantu kepala daerah dalam memelihara ketertiban umum dan ketentraman masyarakat menegakkan qanun, peraturan daerah dan keputusan kepala daerah. Sedangkan secara bagi wilayatul hisbah khusus di bidang syariat Islam.

Dengan demikian, dapat dikatakan di Provinsi Nanggroe Aceh Darussalam peran dan tugas Sat.Pol.PP menjadi lebih luas dengan melaksanakan tugas penegakan Qanun Syariat Islam. Penegakan Syariat Islam dimaksud adalah dengan melakukan pengawasan terhadap pelaksanaan qanun syari'at yang hanya berlaku di di Provinsi Nanggroe Aceh Darussalam.

Satuan Palisi Pamong Praja mempunyai tugas memelihara dan menyelenggarakan ketenteraman dan ketertiban umum, menegakkan Peraturan Daerah dan Keputusan Kepala Daerah. Dalam melaksanakan tugas tersebut Satpol PP menyelenggarakan fungsi, antara lain :

1. Penyusunan program dan pelaksanaan ketenteraman dan ketertiban umum, penegakan Peraturan Daerah dan Keputusan Kepala Daerah;

2. Pelaksanaan kebijakan pemeliharaan dan penyelenggaraan ketenteraman dan ketertiban umum di Daerah;
3. Pelaksanaan kebijakan penegakan Peraturan Daerah dan Keputusan Kepala Daerah;

4. Pelaksanaan koordinasi pemeliharaan dan penyelenggaraan ketenteraman dan ketertiban umum serta penegakan Peraturan Daerah, Keputusan Kepala Daerah dengan aparat Kepolisian Negara, PPNS dan atau aparatur lainnya;

5. Pengawasan terhadap masyarakat agar mematuhi dan menaati Peraturan Daerah dan Keputusan Kepala Daerah.

Dengan memperhatikan pada fungsi Sat Pol PP di atas, yang mencakup fungsi operasi, fungsi koordinasi dan fungsi pengawasan, menunjukkan betapa penting dan strategisnya peran Pol PP dalam menyangga kewibawaan pemerintah daerah serta penciptaan situasi kondusif dalam kehidupan pembangunan bangsa. Oleh karena itu, diperlukan aparatur atau pelaksana tugas yang mampu menjaga kewibawaan pemerintah dan menjadi pelayan masyarakat.

Dalam kaitan dengan pembinaan keamaman, tentunya peran Sat Pol PP tidak dapat diabaikan begitu saja, sebaliknya diharapkan mempunyai tingkat profesionalisme yang tinggi dan selalu bersinergi dengan aparat Polri dan alat-alat kepolisian khusus lainnya serta bermitra dengan masyarakat, yang dapat diwujudkan melalui berbagai tindakan prevemtif, seperti kegiatan penyuluhan, pembinaan dan penggalangan masyarakat. Upaya ini dapat diterapkan guna mencegah secara dini gangguan ketertiban masyarakat dan ketenteraman masyarakat sekaligus dapat menyelesaikan berbagai persoalan yang bersinggungan dengan masyarakat secara arif dan bijaksana.

Di samping itu, pola-pola preventif pun dapat diupayakan guna menanggulangi faktor police hazard yang potensial memunculkan berbagai gangguan Kamtibmas. Khusus berkaitan 
dengan eksistensi Sat Pol PP dalam penegakan hukum (represif), sebagai perangkat pemerintah daerah, kontribusi Sat Pol PP sangat diperlukan guna mendukung suksesnya pelaksanaan Otonomi Daerah. Dengan demikian aparat Pol PP diharapkan menjadi motivator dalam menjamin kepastian pelaksanaan peraturan daerah dan upaya menegakannya di tengah-tengah masyarakat, sekaligus membantu dalam menindak segala bentuk penyelewengan dan penegakkan hukum.

Dalam melaksanakan kewenangannya guna menegakkan peraturan daerah serta keputusan kepala daerah, sebagai salah satu tugas utama dari Pol PP, tentunya tidak semudah membalikkan telapak tangan, terlebih dalam melaksakanan kewenangannya ini Pol PP dibatasi oleh kewenangan represif yang sifatnya non yustisial. Karenanya, aparat Pol PP seringkali harus menghadapi berbagai kendala ketika harus berhadapan dengan masyarakat yang memiliki kepentingan tertentu dalam memperjuangkan kehidupannya, yang akhirnya bermuara pada munculnya konflik (bentrokan) .

Dari keterangan di atas dapat diketahui bahwa dari berbagai fungsi dan peran Sat.Pol.PP sebagaimana diatur dalam ketentuan yang berlaku, dalam pelaksanaannya tidak semuanya berjalan sebagaimana mestinya. Kondisi ini diakibatkan pihak Sat.Pol.PP sering berhadapan dengan dua kepentingan yang berbeda. Di satu sisi harus melakukan penegakan hukum dan di sisi lain dituntut untuk memelihara ketertiban dan keamanan masyarakat sedangkan dalam melakukan penegakan hukum terkadang harus berhadapan dengan tindakan yang menyebabkan timbulnya keresahan dan mengganggu ketertiban dan kenyamanaan warga lainnya.

Kondisi ini menunjukkan bahwa dalam pelaksanaan di lapangan kewenangan, fungsi dan tugasnya merugikan masyarakat karena terlalu represif, dan terkesan arogan sehingga melanggar ketentuan mengenai kewenangan, fungsi dan tugasnya yang diatur Pasal 3, 4 dan Pasal 7 sebagaimana yang telah diuraikan di atas.

Dalam menghadapi situasi ) seperti ini, Pol PP harus dapat mengambil sikap yang tepat dan bijaksana, sesuai dengan paradigma baru Polisi Pamong Praja yaitu menjadi aparat yang ramah, bersahabat, dapat menciptakan suasana batin dan nuansa kesejukan bagi masyarakat, namun tetap tegas dalam bertindak demi tegaknya peraturan yang berlaku. Oleh karena itu, dalam rangka mengantisipasi perkembangan dan dinamika masyarakat seiring dengan tuntutan era globalisasi dan otonomi daerah, setiap personil Pol PP dituntut untuk semakin meningkatkan kinerjanya.

Dari uraian di atas, jelaslah bahwa tugas dan fungsi Satpol PP adalah membantu kepala daerah dalam menegakkan peraturan daerah dan penyelenggaraan ketertiban umum dan ketentraman masyarakat. Dalam menegakkan Peraturan Daerah dan keputusan Kepala Daerah yang dilakukan melalui operasi lapangan, diminta hendaknya bersikap dan bertindak secara profesional. Untuk itu, dalam menjalankan tugasnya Satpol PP tidak dengan cara pendek dan gampang, seperti memaksa dan mengunakan kekerasan belaka. Namun perlu mendengar dan mencari tahu hakikat dari permasalahan masyarakat di daerah. Artinya, anggota Satpol PP sedapat mengkin menghindari kekerasan terbuka (Brute Force) pada cara-cara yang berkemanusiaan.

Berdasarkan uraian di atas, jelaslah bahwa pelaksanaan tugas dan fungsi Satpol PP di Kota Banda Aceh selain dilaksanakan berdasarkan ketentuan yang berlaku nasional juga terdapat ketentuan khusus di Provinsi 
Nanggroe Aceh Darussalam yang dalam hal mi melibatkan Wilayatul Hisbah dalam penegakan syarai'at Islam. Secara umum pelaksanaan tugas dan fungsi Satpol PP adalah dalam rangka pengawasan pemeliharaan dan penyelenggaraan ketenteraman dan ketertiban umum serta pelaksanaan kebijakan penegakan Peraturan Daerah dan Keputusan Kepala Daerah, koordinasi pemeliharaan dan penyelenggaraan ketenteraman dan ketertiban umum serta penegakan Peraturan Daerah, Keputusan Kepala Daerah dengan aparat Kepolisian Negara, PPNS dan atau aparatur lainnya.

\section{B. Hambatan yang Ditemui Dalam Pelaksanaan Kewenangan Satpol PP di Kota Banda Aceh \\ Dalam \\ melaksanakan}

kewenangannya guna menegakkan peraturan daerah serta keputusan kepala daerah, sebagai salah satu tugas utama dari Sat Pol PP, tentunya tidak semudah membalikkan telapak tangan, terlebih dalam melaksakanan kewenangannya ini Pol PP dibatasi oleh kewenangan represifyang sifatnya non yustisial. Dalam kenyataannya, aparat Pol PP seringkali harus menghadapi berbagai kendala ketika harus berhadapan dengan masyarakat yang memiliki kepentingan tertentu dalam memperjuangkan kehidupannya, yang akhimya bermuara pada munculnya konflik (bentrokan).

Kondisi ini muncul gambaran miring terhadap sosok aparat Satpol PP tidak lain dan tidak bukan, karena seringnya masyarakat disuguhi aksi- aksi represif, namun terkesan arogan dari aparat daerah tersebut saat menjalankan perannya dalam memelihara dan menyelenggarakan keamanan dan ketertiban umum. Adapun beberapa tindakan tersebut antara lain pembongkaran bangunan liar, penertiban pedagang kaki lima, PSK dan gelandangan, yang sering berujung bentrokan fisik, merupakan gambaran keseharian yang sering disuguhkan oleh aparat Pol PP, sekalipun tindakantindakan represif tersebut hanyalah sebagian dari fungsi dan peran Pol PP.

Akibatnya masyarakat mencap aparat Pol PP sebagai aparat yang kasar, arogan, penindas masyarakat kecil, serta sebutan-sebutan lain yang tidak enak didengar.

Kesan ini penting untuk diubah dan dibangun oleh Satpol PP, sehingga penyelenggaraan Pemerintahan Daerah dapat berjalan dengan baik. Sesuai bidang tugasnya Satpol PP sering berhadapan dengan masyarakat yang sebagian sudah termasuk moderen. Hal ini berarti dihadapkan kepada kehidupan yang kompleks, baik vertikal maupun horizontal. Oleh karena itu, dalam menjalankan tugasnya Satpol PP, harus menghargai harkat dan martabat rnanusia dan menjadikannya sebagai pertimbangan penting guna memperbaiki citra di rnata masyarakat.

Sisi lain dalam rnenghadapi tugas yang semakin berat, Satpol PP dituntut kesiapan mental, fisik serta harus berani menghadapi tantangan dan kekerasan. Namun ditegaskannya anggota Satpol PP harus menghindari benturan fisik dengan masyarakat. Sebagai manusia biasa, anggota Satpol PP akan menghadapinya dengan rasa takut, marah, curiga, tegang dan emosional. Meski demikian anggota Satpol PP dituntut untuk memberikan respon terhadap emosi masyarakat secara memadai. Menyangkut penerapan HAM, terkait dengan pelaksanaan tugas aparat

Satpol PP dalam penegakan ketentuan hukum serta kebiasaan dan adat istiadat yang hidup dalam masyarakat. Sejalan dengan fungsi membantu kepala daerah dalam penyelenggaraan ketertiban umum dan ketenteraman masyarakat serta pelaksanaan keputusan Kepala 
Daerah dan Perda menjadi semakin penting. Untuk itu operasi-operasi Satpol PP hendaknya tetap berorientasi pada tugas-tugas pemerintahan.

Apabila hal ini terjadi maka PPNS dan SATPOL PP di Aceh akan mengalami kesulitan. Sedang mengenai penuntutan dan pelaksanaan hukuman atas pelanggaran Qanun Aceh termasuk di bidang syari' at Islam, sepenuhnya menjadi tugas kejaksaan, bahkan lebih ketat dari tugas penyidikan tadi, UU No 11 Tahun 2006 kelihatannya tidak membuka peluang bagi aparat di provinsi atau kabupaten untuk ikut membantu petugas kejaksaan ini. Dengan demikian kesulitan yang diduga akan terjadi pada petugas kepolisian di atas, kuat dugaan akan terjadi juga pada petugas kejaksaan ini.

Berdasarkan uraian di atas, dalam kegiatan penegakan hukum di Aceh mungkin 'sekali akan muncul kesulitan dan ketegangan. Aceh diberi izin untuk membuat hukum rnateril dan formil yang akan berlaku di Aceh. Tetapi lembaga (aparat) yang bertugas untuk melaksanakannya khususnya di bidang pidana, boleh dikatakan adalah pihak luar (aparat pusat) yang tidak bertanggung jawab kepada DPRD Provinsi NAD atau Gubernur Provinsi NAD. Lebih dari itu mungkin sekali aparat pusat yang bertugas di Aceh ini tidak menguasai Qanun-qanun Aceh karena mereka memang tidak dididik dan dipersiapkan untuk itu. Keadaan ini menurut penulis harus dicarikan jalan keluarnya, sehingga tidak ada kekuatiran bahwa Qanun Aceh di bidang syariat Islam ini tidak akan terlaksana, tidak akan digunakan oleh aparat penegak hukum dalam penegakan hukum di Aceh.

Dari gambaran di atas dapat dijelaskan bahwa dari pelaksanaan tugas dan fungsi Satpol PP ditemukan sejumlah hambatan antara lain:
1) Kurangnya petunjuk teknis dalam pelaksanaan tugas Satpol PP Kurangnya petunjuk teknis dalam pelaksanaan tugas Satpol PP. Hal ini menyangkut pedoman pelaksanaan tugas lapangan Dinas Ketenteraman dan Ketertiban (Tramtib) - Satpol Polisi Pamong Praja dan PPNS. Dalam hal ini masih kurangnya pedoman pokok yang berasal dari Walikota, padahal dalam hal ini diperlukan pengadaan pedoman petunjuk pelaksanaan tugas-tugas operasional kedinasan berkaitan dengan koordinasi, integrasi, sinkronisasi dan simplikasi sehingga terdapat proses sinergis interdisiplin lembaga terkait yang tidak tumpang tindih khususnya kebijakan operasional dan bahkan penegakan Perda itu sendiri. Pedoman pokok pelaksanaan tugas ini dibuat melalui Surat Keputusan Walikota/Bupati di tingkat Kota/Kabupaten yang didasarkan atas Surat Keputusan Gubernur sebagai tindak lanjut atas Surat Keputusan Menteri Dalam Negeri. Namun tidak terdapat pedoman khusus seperti petunjuk pelaksanaan (juklak) yang secara teknis menjabarkan istilah dan fungsi koordinasi sebagai bentuk kerja sama sinergis dengan instansi lain yang umumnya sudah ada secara tradisi seperti dengan kepolisian, kejaksaan, TNI, Dinas Sosial, Dinas Perhubungan, pengadilan dan lainnya. Namun tingkat intensitasnya relatif bergantung kepada persoalan yang dihadapi di lapangan.

2) Kurangnya sumber daya manusia, anggaran operasional dan sarana prasarana aparat keamanan dan ketertiban. Kurangnya sumber daya manusia, anggaran operasional dan sarana prasarana aparat keamanan dan ketertiban. Menyangkut masalah ini 
ditemukan sisi lemah dari aparat tramtib terutama berkenaan dengan kemampuan skill dan managerial khususnya pemahaman, pendalaman pengetahuan indikator aspek hukum dalam menjalankan tugas-tugas di lapangan. Faktorfaktor penyebab di antaranya kurangnya alokasi dana rutin yang dianggarkan oleh APBD, operasionalisasi kegiatan lebih bersifat projektif, akibatnya sarana dan prasarana yang bersifat fasilitas keperluan dinas tidak memadai. Baik . Satpol PP maupun PPNS umumnya di tiap kota dan kabupaten masih belum cukup secara k:uantitas, apalagi status kepegawaiannya lebih banyak yang bersifat honorer dengan gaji di bawah UMR nasional.

3) Kendala tugas operasional lapangan dan penetapan sanksi.

Kendala tugas operasional lapangan dan penetapan sanksi dan penetapan sanksi yang dimaskud disini adalah sanksi terhadap aparat Satpol PP yang melanggar dalam pelaksanaan tugas dan sanksi apabila melanggar hukum dalam pelaksanaan tugasnya. Hambatan pelaksanaan tugas aparat Satpol PP di luar anggaran rutin umumnya pada pelaksanaan tugas penertiban, terutama masih banyaknya oknum tertentu yang melindungi pelakupelaku pelanggar Perda yang kebanyakan pada sektor hiburan malam dan prostitusi. Sementara itu penerapan sanksi yang bersifat pemaksaan terkendala oleh aturan hukum akibat otoritas yang terbatas khususnya menyangkut sanksi penangkapan, penahanan dan kurungan.

Berdasarkan uraian di atas jelaslah bahwa hambatan yang ditemui dalam pelaksanaan kewenangan Satpol PP di Kota Banda Aceh antara lain (1) kurangnya petunjuk teknis dalam pelaksanaan tugas Satpol PP (aspek regulasi), (2) kurangnya sumber daya manusia, anggaran operasional dan sarana prasarana aparat keamanan dan ketertiban dan (3) kendala tugas operasional lapangan dan penetapan sanksi akibat masih ditemukannya oknum tertentu yang melindungi pelaku pelanggar peraturan daerah.

\section{Upaya Pemerintah Daerah Kota Banda Aceh Dalam Fungsi dan Peran Satuan Polisi Pamong Praja. \\ Dalam menjalankan} tugasnya, dalam rangka pembinaan dan penegakan hukum, Polisi Pamong Praja diharapkan selalu menampilkan performa professional, khususnya dalam menghadapi perkembangan keadaan dan tantangan global. Maka dari itu, segenap aparat Pol PP diharapkan menjadi aparat yang handal dan mempunyai kemampuan pemikiran yang jemih, serta kesehatan dan kemampuan fisik yang prima untuk menunjang keberhasilan dalam tugas-tugas di lapangan.

Namun yang lebih penting lagi tentunya setiap aparat Sat Pol PP harus berupaya menempatkan fungsi pembinaan kepada masyarakat dibandingkan dengan penegakan hukum. Hal ini penting sebagai usaha preventif agar masyarakat sadar hukum (perda) dan paham akan pentingnya ketentraman dan ketertiban umum, mengingat ada kecenderungan ketika penegakan hukum lebih ditonjolkan, potensial bagi terjadi konflik.

Berdasarkan hasil penelitian diketahui bahwa upaya pemerintah daerah Kota Banda Aceh dalam merealisasikan fungsi dan peran Satpol PP, antara lain :

$\begin{array}{llr}\text { 1. Mengupayakan } & \text { Penyusunan } \\ \text { Petunjuk Teknis } & & \\ \text { Sebagaimana diketahui } & \text { bahwa } \\ \text { Satpol PP maupun } & \text { PPNS }\end{array}$


(Penyidik Pegawai Negeri Sipil) merupakan perangkat aparat pelaksana penegak hukum dalam konteks institusi ketentraman dan ketertiban di daerah. Dari berbagai hambatan dan kendala yang dikemukakan sebelumnya terdapat sejumlah indikator peranan yang dapat diperhatikan dari subjek pelaksanaan tugas lapangan. Dalam hal ini menyangkut ada tidaknya pedoman untuk menyusun dan menetapkan serta melaksanakan kebijakan pemerintah daerah dengan ketentuan pokok yang menjadi acuan untuk mewujudkan koordinasi integrasi, sinkronisasi dan simplikasi dalam memelihara dan menegakkan ketenteraman dan ketertiban umum sebagai bentuk perlindungan masyarakat. Dengan demikian, perlu dilakukan dan dibentuk berbagai pentunjuk pelaksana dan petunjuk teknis berkenaan dengan istilah dan fungsi dari pedoman pokok dan juklak menyangkut sinkronisasi, agar tidak terdapat tumpang tindih dan kerancuan dalam kebijakan dan pelaksanaannya yang bisa mengacaukan keberlakuan satu aturan yang satu dengan aturan lainnya.

\section{Mengupayakan} Petunjuk Teknis

Penyusunan Selanjutnya upaya yang dilakukan menyangkut sumberdaya manusia, anggaran. dan sarana dapat dijelaskan bahwa Jumlah Satpol PP di Kota Banda Aceh walaupun telah ditetapkan secara resmi dalam SK Wali Kota namun mengingat tugas yang harus dilaksanakan masih dipandang tidak memadai untuk melakukan penyidikan bagi perkara pelanggaran perda. Dari jumlah yang ada, baik Satpol PP maupun PPNS bermasalah pada status mereka termasuk pula berbagai sarana dan anggaran yang terbatas.

Oleh karena itu, upaya pernerintah daerah dalam meningkatkan kualitas surnber daya manusia (SDM) aparat Satpol PP dalam melaksanakan tugas di lapangan dilakukan oleh harnpir semua anggota Satpol PP. Namun demikian, nilai kualitas personel dipandang masih kurang optimal dan bahkan ada yang sangat tidak memadai sekalipun bentuk pendidikan, penyuluhan, pembekalan, diskusi intensif dan lainnya bersifat: temporer, tidak terprogram dalam skedul rutinitas proses pemberdayaan personel yang dapat dilaksanakan secara berkala.

Berkaitan dengan hal fasilitas, misalnya keperluan petugas Satpol juga masih terbatas. Sebagian anggota Sat Pol berharap agar dalam pelaksanaan tugas-tugas di lapangan sesungguhnya cukup sederhana seperti keperluan mereka akan alat kelengkapan seperti helm pengaman, tameng/perisai pelindung yang acapkali sangat diperlukan manakala mereka harus berhadapan dengan massa yang tidak jarang menimbulkan keberingasan dan bahkan kerusuhan yang dapat membahayakan petugas.

3. Mengupayakan Penyusunan Petunjuk Teknis

Selain kedua upaya di atas, secara intern pihak Sat.Pol.PP dalam hal ini guna menjaga nama baik Sat.Pol.PP juga berupaya untuk melaksanakan tugas di lapangan secara lebih preventif dan menghindari terjadinya kekerasan.

Dari uraian di atas, jelaslah bahwa terhadap berbagai hambatan dalam pelaksanaan tugas Satpol PP telah diupayakan berbagai cara untuk mengatasinya. Oleh karena itu, untuk dapat menghasilkan sosok aparat Sat Pol PP yang professional, khususnya dalam rangka mewujudkan perannya dalam pembinaan dan penegakkan hukum, maka beberapa upaya yang dapat dilakukan, di antaranya:
1. Memantapkan
wawasan,
keterampilan, dan performance 
SDM Pol PP menuju sosok profesionalisme dalam pelaksanaan tugas, salah satunya dengan cara mengubah sistem rekrutmen dan pendidikan aparat Pol PP;

2. Setiap anggota Pol PP hams dibekali kemampuan dan keterampilan taktis dan teknis kepamongprajaan yang memadai. Tujuannya adalah supaya gerak langkah anggota Pol PP dalam melaksanakan perannya semaksimal mungkin terhindar dari tindakan-tindakan yang menyimpang;

3. Evaluasi terhadap pola pendekatan yang selama ini diterapkan untuk menilai kadar efektifitasnya, sekaligus guna meminimalisir kemungkinan penyimpangan; terjadinya

4. Memantapkan pedoman, arah, dan kewenangan yang jelas dan sinergis dengan unsur terkait, sehingga terjalin mekanisme operasional yang efektif dalam mewujudkan situasi yang kondusif wilayahnya;

5. Menjalin kerja sama dengan seluruh aparat keamanan dan ketertiban serta aparat penegak hukum lainnya agar tercipta hubungan yang sinergis, mengingat beberapa kewenangan yang melekat pada Satpol PP.

Berdasarkan uraian di atas jelaslah bahwa upaya pemerintah daerah Kota Banda Aceh dalam merealisasikan fungsi dan peran Satpol PP adalah dengan berupaya memenuhi berbagai pentunjuk pelaksana dan petunjuk teknis dalam pelaksanaan tugas di lapangan, peningkatan sumber daya manusia, anggaran, sarana dan prasarana dalam penyelenggaraan tugas serta menjalin kerja sama dengan apara penegak hukum lainnya termasuk dengan anggota masyarakat.

\section{PENUTUP}

Berdasarkan uraian yang telah dikemukakan diatas, maka pada bagian penutup ini dikemukakan beberapa kesimpulan dan disertai dengan saran.

\section{A. Kesimpulan}

Pelaksanaan tugas dan fungsi Satpol PP di Kota Banda Aceh diatur dalam Peraturan Walikota Nomor 44 Tahun 2009 khususnya pada Pasal 3 dan Pasal 4 yang meliputi menyelenggarakan ketentraman dan ketertiban umum, menegakkan Peraturan Daerah dan atau Qanun Peraturan Walikota, Keputusan Walikota, dan pelaksanaan syariat Islam serta melakukan sosialisasi, pengawasan, pembinaan, penyidikan dan pelaksanaan peratuan perundangundangan dan advokasi syariat Islam dan bekerja sama dengan kepolisian negara, Penyidik Pegawai Negeri Spil (PPNS) dan aparatur lainnya. Namun dalam pelaksanaannya, tidak sepenuhnya dapat dilaksanakan akibat berbagai hambatan baik yang bersifat internal maupun ekstemal.

1. Hambatan yang ditemui dalam pelaksanaan kewenangan Satpol PP di Kota Banda Aceh antara lain (1) kurangnya petunjuk teknis dalam pelaksanaan tugas Satpol PP (aspek regulasi), (2) kurangnya sumber daya manusia, anggaran operasional dan sarana prasarana aparat keamanan dan ketertiban dan (3) kendala tugas operasional lapangan dan penetapan sanksi akibat masih ditemukannya oknum tertentu yang melindungi pelaku-pelaku pelanggar peraturan daerah.

2. Upaya pemerintah daerah Kota Banda Aceh dalam merealisasikan fungsi dan peran Satpol PP adalah 
dengan berupaya memenuhi berbagai pentunjuk pelaksana dan petunjuk teknis dalam pelaksanaah tugas di lapangan, peningkatan sumber daya manusia, anggaran, sarana dan prasarana dalam penyelenggaraan tugas serta menjalin kerja sama dengan apara penegak hukum lainnya termasuk dengan anggota masyarakat.

\section{B. Saran}

1. Disarankan agar masyarakat dapat memenuhi berbagai ketentuan dan kebijakan daerah sehingga terhindar dari pertentangan dengan aparatur penegakan peraturan daerah.

2. Disarankan kepada aparat Satpol PP agar dapat menghindari tindakan yang arogan guna mengambil simpati masyarakat dan menghilangkan persepsi negatif terhadap Sat Pol PP

3. Disarankan kepada penyelenggara pemerintahan agar dapat mengambil kebijakan yang tepat di bidang penegakan hukum guna memberikan citra positif terhadap alat kelengkapan dan penegakan hukum pemerintahan kepada masyarakat.

\section{DAFTAR PUSTAKA}

\section{A. Buku-buku}

Abu Bakar Busro, Dasar-dasar Hukum Tata Negara, Ghalia Indonesia, Jakarta, 1985.

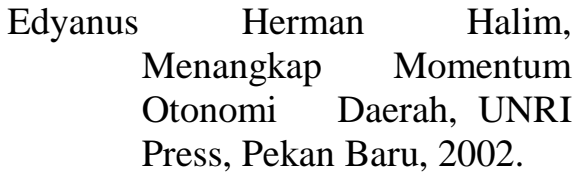

Hasan Zaini, Pengantar Hukum Tata Negara Indonesia, Alumni, Bandung, 1985.

Inu Kencana Syafiie, Sistem Pemerintahan Indonesia, Rineka Cipta, Jakarta, 2002.

Jimly Asshiddiqie, Konstitusi dan Konstitusionalisme

Indonesia, Pusat Studi HTN FH-UI, Jakarta, 2004.

Kaloh. J., Mencari Bentuk Otonomi Daerah, Rineka Cipta, Jakarta, 2002.

Ni'matul Huda, Otonomi Daerah Filsofofi, Sejarah Perkembangannya, dan Problematika. Pustaka Pelajar, Yogyakarta 2005.

Syarif Hidayat, Rejleks Realitas Otonomi Daerah , Pustaka Quantum, Jakarta 2000.

Syaukani, Afan Gaffar, dan M. Ryaas Rasyid, Otonomi Daerah Dalam Negara Kesatuan, Kerjasama Pustaka Pelajar dan PUSKAP, Yogyakarta, 2002.

\section{A. Perundang-undangan}

Undang-Undang No. 2 Tahun 2002 tentang Kepolisian Negara Republik Indonesia

Undang-Undang Nomor 32 Tahun 2004 tentang Pemerintahan Daerah 
Jurnal Sosial Humaniora Sigli (JSH)

p ISSN : 2615-3688

$e$ ISSN : 2716-0270

http://journal.unigha.ac.id/index.php/JSH

Undang-Undang No. 11 Tahun

2006 tentang Pemerintahan

Aceh

Pemerintah Republik Indonesia

Nomor 32 Tahun 2004

Tentang Pedoman Satuan

Polisi Pamong Praja 